\title{
Growth Characteristies of Influenza Virus Type C in Avian Hosts
}

\author{
Brief Report
}

\author{
By \\ Mary Ann D. Austin, A. S. Monto, and H. F. MaAssab \\ Department of Epidemiology, The University of Michigan, \\ Ann Arbor, Michigan, U.S.A.
}

With 1 Figure

Accepted July 28, 1978

\begin{abstract}
Summary
Influenza virus type $\mathrm{C}$ could be propagated to high yield in primary chick embryo kidney cell culture (PCEK) provided that trypsin $(2 \mu \mathrm{g} / \mathrm{ml})$ was used as a medium supplement. The virus could also be titrated by plaque assay using PCEK host cells and influenza $\mathrm{C}$ virus that had been plaque-purified in PCEK cells could then be serially passaged to high titer using the allantoic route of 10-11-day-old embryonated eggs.

The study of influenza type $\mathrm{C}$ has been hampered by the lack of an efficient tissue culture system which would support its growth, so that inoculation of the amniotic sac of embryonated eggs has been the primary method used for the propagation of this virus. Recently characterization of the structural components and polypeptide composition of the virus grown in this way has been reported. It appears that influenza type $\mathrm{C}$ has a segmented single-strand RNA genome and shares some other similarities with influenza $A$ and $B$ viruses $(3,4,6,12)$, although the virus differs from other myxoviruses since it lacks an $\alpha$-neuraminidase (3).

Attempts to propagate the virus in tissue culture have been made using various cell cultures systems with some success $(2,7,10,11)$. The most recent being a report of viral replication in MDCK cells in the presence of trypsin (10). In our hand, the treatment of MDCK line with high trypsin concentration $(20 \mu \mathrm{g} / \mathrm{ml})$ was not tolerated by the cells. Primary chick kidney cells have been useful for propagation of many strains of influenza $A$ and $B$ viruses (8) and LoBodzinskA (7) has claimed some success with the use of primary chick embryo kidney cells (PCEK) for the growth of influenza type C. However, no detailed studies were reported. In this communication we describe the successful serial propagation of influenza $\mathrm{C}$ virus in PCEK cells and the isolation of a clone which produces plaques in PCEK cells and grows to high titer in the allantoic cavity of eggs.
\end{abstract}


Conventional tissue culture techniques were used to establish PCEK cell monolayers. Briefly, kidneys were excised from 18-day-old chicken embryos and were processed according to a previously published method (8). Monolayers of cells became confluent between the third and fourth day after seeding. Cells were washed with Hanks" balanced salt solution (BSS) before being infected with the appropriate dilutions of the virus. The inoculum was adsorbed for 1 hour at $35^{\circ} \mathrm{C}$, removed and cells maintained at $35^{\circ} \mathrm{C}$ in $2 \times$ Eagle basal medium supplemented with Worthington-TPCK trypsin $(2 \mu \mathrm{g} / \mathrm{ml})$ and 0.1 per cent fraction $V$ of bovine serum albumin (BSA). After incubation for 48 to 72 hours, the extracellular fluid was removed and tested for hemagglutination activity at $4^{\circ} \mathrm{C}$ using 0.5 per cent chicken red blood cells.

When influenza $\mathrm{C}$ was titrated by plaque assay, infected monolayers were covered with an agar overlay after an adsorption period of 1 hour at $35^{\circ} \mathrm{C}$. The composition of the agar overlay was as described by Sugtura and KILBourne (13) for the Chang conjunctival cell line clone $1-5 \mathrm{~cm} 4$, but modified to contain a final agar concentration of 1.2 per cent and trypsin at a final concentration of $2 \mu \mathrm{g} / \mathrm{ml}$. After incubation for 2 to 3 days at $35^{\circ} \mathrm{C}$ a second overlay of agar was added with a composition similar to that in the original overlay but also containing $60 \mu \mathrm{g} / \mathrm{ml}$ neutral red, and the cultures were returned to $35^{\circ} \mathrm{C}$ for further incubation.

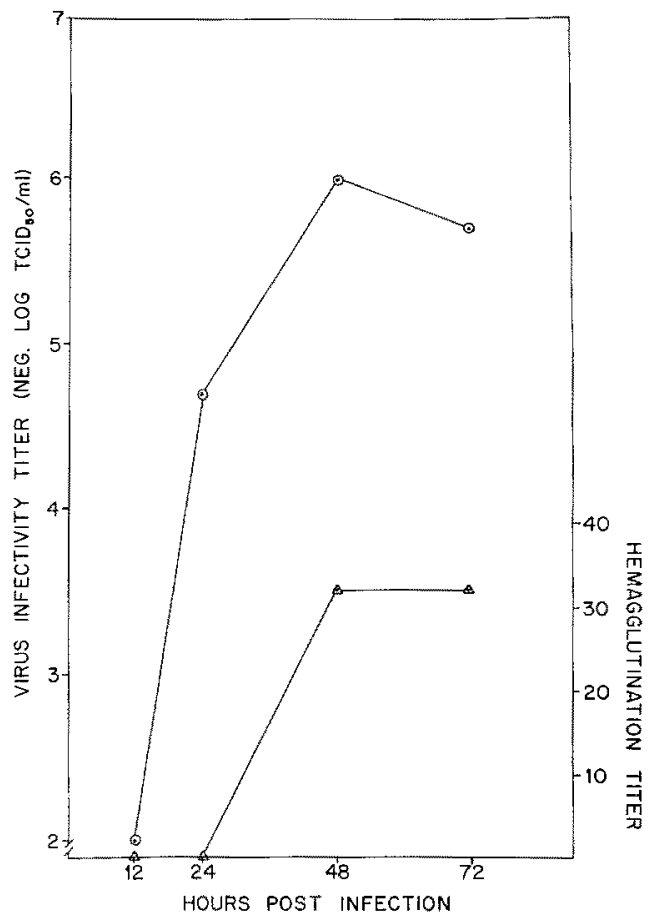

Fig. 1. Influenza $\mathrm{C}$ growth in primary chick embryo kidney cells. Virus yields were determined for supernatant fluids harvested at the indicated times after infection of cell monolayers at $35^{\circ} \mathrm{C}$ with influenza $\mathrm{C} / \mathrm{Ann}$ Arbor/1/50 at a multiplicity of infection (MOI) of $10 \mathrm{EID}$ o/cell in the presence of $2 \mu \mathrm{g}$ trypsin $/ \mathrm{ml}$. Symbols: $0-0$ : infectivity; $\triangle-\Delta: H A$ 
The strain of influenza $\mathrm{C}$ used was C/Ann Arbor/1/50 that had been isolated in this laboratory $(5,9)$ and had a history of 33 amniotic passages in embryonated chicken eggs. As originally reported, the virus failed to be passaged serially when inoculated into the allantoic cavity of eggs. When inoculated into PCEK cells at a multiplicity of $10 \mathrm{EID}_{50} /$ cell, the virus grew to maximum titer between 48 to 72 hours after infection (Fig. 1). The rate of appearance of cytopathic changes paralleled virus growth and CPE was apparent at 48 hours and was maximal as evidenced by cell detachment at 72 hours post-infection (p. i.).

After 9 serial passages in chick embryo kidney cells, the virus was titrated by plaque assay in the same system. Distinct plaques were evident which increased in size with duration of incubation. Clones were picked at various times up to the sixth day p. i. and inoculated directly into the allantoic sac of embryonated eggs. Further studies were done using elone 2 picked on the fourth day p. i. since it produced high yields of both hemagglutinin and infectious virus upon inoculation of the allantoic sac of embryonated eggs. Results of the serial passages of clone 2 in the allantoic cavity of embryonated eggs are shown in Table 1. It is apparent that upon serial passages using the allantoic route virus growth was consistent with high $\mathrm{HA}$ and infeetivity titers. In addition, it was found that trypsin was not necessary as a additive in the diluent for the allantoic inoculation. A comparison. of titrations of the original seed virus and of the allantoic fluid stock of clone 2 by egg inoculation using the allantoic route and plaque assay is shown in Table 2 .

Table 1. Hemagglutination and infectivity titers of clone 2 after serial passages in embryonated eggs using the allantoic route

\begin{tabular}{lllll}
\hline Virus & $\begin{array}{c}\text { Passage } \\
\text { history }\end{array}$ & HA titer & EID $_{50 / \mathrm{ml}^{\mathrm{c}}}$ & PFU/ml $^{\mathrm{d}}$ \\
\hline C/AA/1/50 & & & & \\
AE33 PCEK 9 Clone 2 & E 1 & $1: 64$ & $10^{6}$ & N.D.e \\
& E2 & $1: 256$ & N.D. & N.D. \\
& E 3 & $1: 256$ & N.D. & N.D. \\
& E 4 & $1: 256$ & N.D. & N.D. \\
& E5 & $1: 512$ & $10^{8.5}$ & $6 \times 10^{7}$ \\
& E6 6 & $1: 128$ & $10^{8.5}$ & N.D. \\
\hline
\end{tabular}

a. No. of passages in the allantoic cavity of embryonated eggs

i Hemagglutination titer using 0.5 per cent fowl red blood cells at $4^{\circ} \mathrm{C}$

c $\mathrm{EID}_{50} / \mathrm{ml}=\mathrm{Egg}$ infectious dose 50 using the allantoic route of inoculation

a In PCEK cells, incorporating trypsin (TPCK) at a concentration of $2 \mu \mathrm{g} / \mathrm{ml}$

e Not done

Table 2. Hemagglutination and infectivity titers of a clone of C/Ann Arbor/1/50 after 9 passages in PCEK cells and 5 passages in the allontois of 11 day-old embryonated eggs

\begin{tabular}{llll}
\hline Virus & HA titer & EID $_{50} / \mathrm{ml}^{\mathrm{a}}$ & ${\text { PFU } / \mathrm{ml}^{\mathrm{b}}}^{\mathrm{a}}$ \\
\hline C/AA/1/50 AE 33 & $1: 128$ & $10^{3.5}$ & No plaques \\
C/AA/1/50 & & & $6 \times 10^{7}$ \\
AE33 PCEK 9 Clone 2 E5 & $1: 512$ & $10^{\circ} .5$ & 6 \\
\hline
\end{tabular}

ॠ EID $_{50} / \mathrm{ml}=$ Egg infectious dose 50 using the allantoic route of inoculation

b $\mathrm{PFU} / \mathrm{ml}=$ Plaque-forming units per $\mathrm{ml}$ in PCEK cells, incorporating trypsin at a concentration of $2 \mu \mathrm{g} / \mathrm{ml}$

- AF $33=33$ passages in the amniotic cavity of embryonated eggs. $E=$ No. of passages in the allantoic cavity of embryonated eggs 
The infectivity of the original seed virus when propagated in the allantoic cavity of embryonated eggs is low when compared to that of clone 2. In addition, the original virus did not form plaques as did the allantoic fluid stock of clone 2 . It is evident that propagation in PCEK cells increased both the infectivity and plaqueforming ability of the virus.

The identity of this virus as influenza $C$ was accomplished using the hemagglutination-inhibition test (HAI) with antiserum prepared in this laboratory in 1972 by intranasal infection of ferrets with C/Ann Arbor/1/50 using the original seed virus. Antiserum to the strain C/Taylor/1233/47 (obtained from Dr. Alan P. Kendal of the Center for Disease. Control, Atlanta) also inhibited the plaquepurified, allantoically-grown stock of influenza C/Ann Arbor/1/50 (clone 2).

Thus the PCEK tissue culture system supported the replication of influenza $\mathrm{C}$ virus, and enabled us to plaque purify the strain and isolate a clone that grows to high titer not only in the PCEK cells (providing trypsin is present) but also that reproducibly grows to high titer in the allantoic cavity of embryonated eggs. Preliminary results suggest the PCEK system also supports the replication of the recently isolated influenza $\mathrm{C}$ strain $\mathrm{C} / \mathrm{New}$ Jersey/1/76 lobtained from Dr. Kendal CDC). The availability of the avian host cell system for growth of influenza $\mathrm{C}$ ar the isolation of a clone growing to high titer in the allantoic cavity of eggs, may expected to facilitate biochemical and genetic analysis of the virus. Since $h$ factors have often been observed to influence results obtained when studying structure, replication and biological properties of influenza $A$ and $B$ virus, should be valuable now to have the PCEK cell system as an alternative to MDCK cells, which have recently also been reported to support replication of influenza $C$ (10).

\section{Acknowledgments}

The authors wish to thank Dr. Alan P. Kendal of the Center for Disease Control for his helpful comments concerning this manuscript.

\section{References}

1. BEARE, A. S., KEAST, K. A.: Influenza virus plaque formation in different species of cell monolayers. J. gen. Virol, 22, 347-354 (1974).

2. ChaKraverty, P.: The detection and multiplication of influenza $C$ virus in tissue culture. J. gen. Virol. 25, 421-425 (1974).

3. Compans, R. W., Bishop, D. H. L., Meier-Ewhrm, H.: Structural components of influenza $\mathrm{C}$ virions. J. Virol. 21, 658-665 (1977).

4. Cox, N. J., Kendat, A. P.: Presence of a segmented single-stranded RNA genome in influenza, $\mathrm{C}$ virus. Virology 74, $239-241$ (1976).

5. Francis, T., QullitiaAN, J. J., Minuse, E.: Identification of another epidemic respiratory disease. Seience 112, 495-497(1950).

6. KeNDAL, A. P.: A comparison of "Influenza C" with prototype myxoviruses: receptor-destroying activity (neuraminidase) and structural polypeptides. Virology $65,87-99(1975)$.

7. Lobodzinska, M.: Reproduction of Influenza C Taylor 1233 virus in various tissue systems. Arch. Immunol. Ther. Exp. 20, 497--505 (1972).

8. MAASSAB, E. F.: The propagation of multiple viruses in chick kidney cultures. Proc. Nat. Acad. Sci. U.S.A. 45, 1035-1039 (1959).

9. Mrnuse, Quilligan, J. J., Francis, T.: Type C influenza virus. I. Studies of the virus and its distribution. J. Lab. clin. Med. 43, 31-42 (1954). 
10. NERome, K., IsHTda, M. : The multiplication of an influenza $\mathrm{C}$ virus in an established line of canine kidney (MDCK) cells. J. gen. Virol. 39, 179-181 (1978).

11. O'Callaghan, R. J., Lovghlin, M., Labat, D. D., Howe, C.: Properties of influenza $\mathrm{C}$ virus grown in cell culture. J. Virol. 24, 875-882 (1977).

12. Ritchey, M. B., Palese, P., Kilbourne, E. D.: RNAs of influenza A, B and C viruses. J. Virol. 18, 738-744 (1976).

13. Sugtura, A., Krlbourne, E. D.: Genetic studies of influenza viruses. II. Plaque formation by influenza viruses in a clone of a variant human heteroploid cell line. Virology 26, 478-488 (1965).

Authors' address: Prof. Dr. H. F. MaAssab, School of Public Health, The University of Michigan, 109 Observatory Street, Ann Arbor, MI 48109, U.S.A.

Received July 24, 1978 